\title{
Study on the existence of food born microflora and their drug resistant profile isolated from some fermented and non-fermented foods commonly available in Bangladesh
}

\author{
Tasnuva Nusrat Jane, Nafisa Tabassum and Mrityunjoy Acharjee*
}

Department of Microbiology, Stamford University Bangladesh, 51, Siddeswari Road, Dhaka 1217, Bangladesh

Received 15 May 2018/Accepted 27 June 2018

\begin{abstract}
Present study depicted a complete microbiological profile of some popular fermented and nonfermented foods available in different food shops and restaurants in Dhaka city, Bangladesh. Furthermore, All the isolated strain were prepared to determine their survivability against some common synthetic drug through Kirby Bouer method. Total 60 samples of 20 categories $(10$ fermented and 10 non-fermented) unveiled the contaminating microbial flora up to $10^{7} \mathrm{cfu} / \mathrm{g}$ including total viable bacteria and fungi in case of non-fermented food while the contamination rate was extremely low up to $10^{5} \mathrm{cfu} / \mathrm{g}$ in fermented food. Exploration of specific pathogenic bacteria was estimated such as $E$. coli, Salmonella spp, Vibrio spp., Staphylococcus spp. and Pseudomonas spp. within the range of $10^{2}$ to $10^{4} \mathrm{cfu} / \mathrm{g}$ in non-fermented foods whereas only the Staphylococcus spp. was present in fermented food up to $10^{3} \mathrm{cfu} / \mathrm{g}$. Among all the specific pathogens Salmonella spp., Vibrio spp. and Staphylococcus were significantly propagated in all categories of non-fermented samples up- to $10^{4} \mathrm{cfu} / \mathrm{g}$. Total 17 available drugs were used against the identified bacterial strain. Most of the identified bacteria from fermented foods were found to be sensitive against commonly used antibiotics. Subsequently, five isolates from non-fermented foods were found to be $\mathbf{1 0 0 \%}$ resistant against more than one antibiotic as multi drug resistant (MDR).
\end{abstract}

Key words: Microbiological analysis; Fermented food; Non-fermented food, Antibiogram

The consistent monitoring of food quality is very essential to eradicate the existence of food associated pathogens as well as to ensure the consumers' health safety (1-5). Most of the cases, the poor sanitation practices are the major issue behind the long history of food borne diseases particularly in the poor community peoples (6). Beside the poor countries, the occurrence of food borne syndrome is now very common in many developed countries like United States and other European countries which may sometimes causes the morbidity and mortality (6, 7-9). According to the previous research reports, various bacterial species and fungal population are responsible for the contamination of food during the harvesting, processing, storage, shipping, food preparation, kitchen utensils including the cutting boards or other surfaces etc. (10-15). However, fermented foods are one of the major habitat of several indigenous microorganisms those have huge influences to modify the food substrates biochemically and organoleptically (16-18). The presence of fermentative microflora can increase the shelf life of fermented food as well as increase the products

*Corresponding Author: Mailing address. Mrityunjoy Acharjee, Assistant Professor, Department of Microbiology, Stamford University Bangladesh, 51 Siddeswari Road, Dhaka 1217, Bangladesh, Bangladesh; E-mail: mrityunjoy_111@yahoo.com. acceptability to the consumers (19-23). During fermentation the chemical composition of raw materials of food is converted by the microbial action not only to enrich the nutritional value in some fermented foods but also impart health-benefits to the consumers (23, 24-26).

Several researchers have reviewed the microbiology, biochemistry, and nutritional status of fermented foods and beverages previously from different countries in Asia $(16,17,23,25,27,28)$. Several groups have been reported previously on the antibiotic resistant trait of pathogens found in different food items including fermented food (29-32). Both the developing and developed countries are now suffering with food borne infections due to the widespread of drug resistant bacteria through contaminated food and water (32). Considering all these facts, the present study attempted to (1) introduce the microbiological profiling of some common fermented and non-fermented food as well as (2) to describe the drug resistant attribute of the isolates.

\section{MATERIALS AND METHODS}

Study area, sampling, sample processing and microbiological analysis. Total 60 samples of 20 categories $(n=3)$ of food were randomly collected during July 2016 to September 2016 following standard protocol (34). Among 20 categories, 10 were fermented and 10 were non-fermented. All the samples were quickly transported into the laboratory for microbiological assay. $10 \mathrm{~g}$ of each sample was homogenized with $90 \mathrm{ml}$ of buffer peptone water $(\mathrm{pH} 7.2 \pm 0.2)$ in 9:1 ratio and serially diluted up to $10^{-5}$. 
Total 60 samples of 20 categories $(n=3)$ of foods were randomly collected during July 2016 to September 2016 following standard protocol (34). Among 20 categories 10 were fermented and 10 were non-fermented. All the samples were quickly transported into the laboratory for microbiological assay. $10 \mathrm{~g}$ of each sample was homogenized with $90 \mathrm{ml}$ of buffer peptone water $(\mathrm{pH} 7.2 \pm$ 0.2 ) in 9:1 ratio and serially diluted up to $10^{-5}$.

From the dilution $10^{-3}$ each of the samples of $0.1 \mathrm{ml}$ was introduced on to the nutrient agar and Sabouraud dextrose agar for the isolation of total viable bacteria and fungi, respectively. Subsequently, MacConkey agar, Membrane Fecal Coliform agar (M-FC), Manitol Salt agar, Cetrimide agar, SamlnomellaShigella agar, TCBS agar and MRS agar were used as selective media for the quantification of coliforms, fecal coliforms, Staphylococcus spp. Pseudomonas spp., Salmonella spp., Shigella spp., Vibrio spp. and Lactobacillus consecutively $(35,36)$. All the inoculated plates were incubated at $37{ }^{\circ} \mathrm{C}$ for 24 hours except SDA plates, which were incubated at $25^{\circ} \mathrm{C}$ for 48 hours.

Biochemical identification of the isolates. The biochemical properties of identified isolates were confirmed through standard biochemical methods (35, 37)

Antibiotic susceptibility test of the identified bacteria. The pathogenic isolates were examined for the detection of antibiotic susceptibility traits (either drug resistant or sensitive) by disc diffusion assay on Mueller-Hinton agar (Difco, Detroit, MI) against commonly used antibiotics following the standard protocol $(38,39)$. Lawns of bacterial suspensions including Escherichia coli, Pseudomonas spp., Vibrio spp., Staphylococcus spp.and Salmonella spp. (turbidity compared with the McFarland standard $\mathrm{OD}_{600^{-}}-0.5$ ) were prepared and introduced on to Muller Hinton agar. Some common antibiotics such as polymixin B (300 unit), Kanamycin $(30 \mu \mathrm{g})$, methicillin $(30 \mu \mathrm{g})$, streptomycin $(10 \mu \mathrm{g})$, vancomycin $(30 \mu \mathrm{g})$, gentamycin $(10 \mu \mathrm{g})$, nalidixic acid $(30 \mu \mathrm{g})$, azythromycin $(15 \mu \mathrm{g})$, penicillin $\mathrm{G}(10 \mu \mathrm{g})$, erythromycin $(15 \mu \mathrm{g})$, amoxicillin (30 $\mu \mathrm{g})$, ceftriaxone $(30 \mu \mathrm{g})$, ciprofloxacin $(5 \mu \mathrm{g})$, ampicillin $(10 \mu \mathrm{g})$, tetracycline $(30 \mu \mathrm{g})$, chloramphenicol $(30 \mu \mathrm{g})$ and cefixime $(5 \mu \mathrm{g})$ were introduced against the target bacteria. All the plates were incubated at $37^{\circ} \mathrm{C}$ for 12-18 hours and examined for formation of the zone of inhibitions ( $\mathrm{mm})$.

\section{RESULTS AND DISCUSSION}

Propagation of different pathogens including coliform and fecal coliform in different food samples due to the poor sanitation and hygienic condition are the main causative agent of several food born diseases particularly diarrhea and dysentery (23). Such diseases are very common in developing countries like Bangladesh due to the lack of proper knowledge on personnel hygiene as well as poor maintenance quality of raw materials (11, 23).

Existence of pathogenic bacteria in fermented and non-fermented foods. Among the 20 samples (10 fermented and 10 non-fermented) the contamination were highly observed in non-fermented foods up to $10^{7} \mathrm{cfu} / \mathrm{g}$ in case of total viable bacteria and fungi while the load was noticed up to $10^{5} \mathrm{cfu} / \mathrm{g}$ for total viable bacteria and fungi in fermented foods (table 1). For the detection of specific pathogen, present study revealed the contamination rate was very noticeable for non-fermented foods rather than the fermented foods (table 1). All the non-fermented food (raw milk, cake, fuska, vegetable roll, chop, singara, chips, chicken ball, chicken fry, and fried rice) were found to be contaminated with Salmonella spp., Vibrio

TABLE 1. Microbiological profiling of some fermented and non-fermented foods

\begin{tabular}{|c|c|c|c|c|c|c|c|c|}
\hline \multirow{2}{*}{$\begin{array}{l}\text { Samples } \\
\text { name }\end{array}$} & \multicolumn{8}{|c|}{ Microbial load (cfu/g) } \\
\hline & TVB & Fungi & E. coli & $\begin{array}{l}\text { Salmonella } \\
\text { spp. }\end{array}$ & $\begin{array}{l}\text { Vibrio } \\
\text { spp. }\end{array}$ & $\begin{array}{c}\text { Staphylococcus } \\
\text { spp. }\end{array}$ & $\begin{array}{l}\text { Pseudomonas } \\
\text { spp. }\end{array}$ & $\begin{array}{c}\text { Lactobacillus } \\
\text { spp }\end{array}$ \\
\hline \multicolumn{9}{|c|}{ Fermented Food (3 samples each) } \\
\hline Yogurt & $4.0 \times 10^{5}$ & $2.7 \times 10^{3}$ & 0 & 0 & 0 & $4.3 \times 10^{3}$ & 0 & $4.7 \times 10^{2}$ \\
\hline Cheese & $7.5 \times 10^{5}$ & $4.7 \times 10^{4}$ & 0 & 0 & 0 & $7.0 \times 10^{2}$ & 0 & $3.5 \times 10^{3}$ \\
\hline Lassi & $2.5 \times 10^{4}$ & 0 & 0 & 0 & 0 & $2.9 \times 10^{3}$ & 0 & $2.9 \times 10^{4}$ \\
\hline Pickle & $3.5 \times 10^{4}$ & $5.5 \times 10^{3}$ & 0 & 0 & 0 & $3.5 \times 10^{3}$ & 0 & 0 \\
\hline $\begin{array}{l}\text { Soya } \\
\text { sauce }\end{array}$ & $2.0 \times 10^{4}$ & $2.1 \times 10^{3}$ & 0 & 0 & 0 & $2.8 \times 10^{4}$ & 0 & 0 \\
\hline $\begin{array}{l}\text { Fish } \\
\text { sauce }\end{array}$ & $1.5 \times 10^{5}$ & $4.0 \times 10^{3}$ & 0 & 0 & 0 & $1.5 \times 10^{3}$ & 0 & 0 \\
\hline $\begin{array}{c}\text { Sardine tomato } \\
\text { sauce with chilli }\end{array}$ & $4.5 \times 10^{4}$ & $7.0 \times 10^{3}$ & 0 & 0 & 0 & $4.0 \times 10^{4}$ & 0 & 0 \\
\hline \multicolumn{9}{|c|}{ Non fermented Food (3 samples each) } \\
\hline Raw Milk & $2.5 \times 10^{7}$ & $7.5 \times 10^{6}$ & $2.3 \times 10^{2}$ & $2.8 \times 10^{3}$ & $3.8 \times 10^{3}$ & $2.0 \times 10^{3}$ & 0 & $5.2 \times 10^{3}$ \\
\hline Cake & $1.7 \times 10^{6}$ & $3.5 \times 10^{5}$ & $1.9 \times 10^{3}$ & $1.7 \times 10^{4}$ & $1.0 \times 10^{3}$ & $3.3 \times 10^{3}$ & 0 & 0 \\
\hline Fuska & $2.0 \times 10^{7}$ & $2.8 \times 10^{6}$ & $2.0 \times 10^{3}$ & $4.5 \times 10^{4}$ & $5.5 \times 10^{3}$ & $7.5 \times 10^{2}$ & 0 & 0 \\
\hline $\begin{array}{l}\text { Vegetable } \\
\text { roll }\end{array}$ & $4.0 \times 10^{7}$ & $4.0 \times 10^{5}$ & $4.7 \times 10^{3}$ & $1.1 \times 10^{3}$ & $1.8 \times 10^{4}$ & $2.3 \times 10^{3}$ & $5.8 \times 10^{4}$ & 0 \\
\hline Chop & $3.8 \times 10^{6}$ & $3.5 \times 10^{4}$ & $3.0 \times 10^{2}$ & $4.7 \times 10^{4}$ & $4.5 \times 10^{3}$ & $5.7 \times 10^{3}$ & $4.2 \times 10^{3}$ & 0 \\
\hline Singara & $2.8 \times 10^{7}$ & $2.9 \times 10^{5}$ & $2.1 \times 10^{3}$ & $5.7 \times 10^{3}$ & $3.7 \times 10^{4}$ & $3.0 \times 10^{4}$ & $3.0 \times 10^{2}$ & 0 \\
\hline Chips & $4.0 \times 10^{7}$ & $4.0 \times 10^{5}$ & 0 & $2.0 \times 10^{3}$ & $2.0 \times 10^{3}$ & $2.3 \times 10^{3}$ & $2.0 \times 10^{3}$ & 0 \\
\hline $\begin{array}{c}\text { Chicken } \\
\text { ball }\end{array}$ & $5.5 \times 10^{7}$ & $7.3 \times 10^{5}$ & 0 & $4.4 \times 10^{4}$ & $4.5 \times 10^{3}$ & $1.0 \times 10^{3}$ & $4.0 \times 10^{3}$ & 0 \\
\hline $\begin{array}{l}\text { Chicken } \\
\text { Fry }\end{array}$ & $2.8 \times 10^{6}$ & $2.5 \times 10^{4}$ & 0 & $6.0 \times 10^{3}$ & $6.7 \times 10^{4}$ & $4.3 \times 10^{4}$ & 0 & 0 \\
\hline $\begin{array}{l}\text { Fried } \\
\text { rice }\end{array}$ & $4.7 \times 10^{7}$ & $4.8 \times 10^{5}$ & $2.7 \times 10^{2}$ & $2.7 \times 10^{3}$ & $1.8 \times 10^{3}$ & $1.8 \times 10^{3}$ & 0 & 0 \\
\hline
\end{tabular}


spp., and Staphylococcus spp. within the range of $10^{2} \mathrm{cfu} / \mathrm{g}$ to $10^{4} \mathrm{cfu} / \mathrm{g}$. The presence of E. coli as a fecal coliform was noticed in raw milk, cake, fuska, vegetable roll, chop, singaraand fried rice up to $10^{3} \mathrm{cfu} / \mathrm{g}$ while the growth of Pseudomonas spp. was found in vegetable roll, chop, singara, chips, and chicken ball up to $10^{4} \mathrm{cfu} / \mathrm{g}$ (table 1). Only one sample (raw milk) exhibited the presence of Lactobacillus spp., as a selective microflora. Couple of previous study investigated that the existence of contaminating microflora in food samples may occur during the processing of raw material, mixing of ingredients and packaging of the end products $(34,40-43)$. According to the recommendation of International Commission on Microbiological Specifications for Foods (44), the marginal limit of specific pathogen in food should be less than $10^{3} \mathrm{cfu} / \mathrm{g}$. In this study maximum nonfermented food harbored excessive amount of pathogens which exceeded the marginal limit provided by International Commission on Microbiological Specifications for Foods (44). In case of fermented food the bacterial proliferation was significantly low only Staphylococcus spp. was found within the range of
$10^{2}$ to $10^{3} \mathrm{cfu} / \mathrm{g}$ (table 1 ). Total viable bacteria and fungi were found in all the samples up to $10^{5} \mathrm{cfu} / \mathrm{g}$. In few samples (bread, yogurt and cheese) Lactobacillus spp. was found up to $10^{3} \mathrm{cfu} / \mathrm{g}$. As reported in many studies, the fermented foods are extremely treated with various microorganisms especially lactic acid bacteria or enzymes which can improve the quality of fermented food by changing their biochemical properties $(45,46)$. However, some diseases cauusing bacteria such as Streptococcus spp., Staphylococcus spp., Bacillus, Camphylobacter and Pseudomonas were also found in fermented foods (47). Total five types of isolates were identified according to their response against different carbohydrade and chemical reagent.

Proliferation of drug-resistant bacteria in fermented and non-fermented food samples. To evaluate the efficacy of commonly available antibiotics as well as the clinical significance of the bacterial isolates, present study introduced antibiotic susceptibility test. Identified bacterial isolates were experimented to determine the antibiotic susceptibility against the commonly antibiotics. In case of fermented foods most of the bacterial strains were found to be sensitive against most of the antibiotic

TABLE 2. Antibacterial susceptibility test of the isolates

\begin{tabular}{|c|c|c|c|c|c|c|c|c|c|c|c|c|c|c|c|}
\hline \multirow{3}{*}{ Antibiotic } & \multicolumn{5}{|c|}{ Fermented foods } & \multicolumn{10}{|c|}{ Non-fermented foods } \\
\hline & \multirow[t]{2}{*}{ 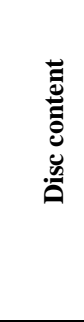 } & \multicolumn{2}{|c|}{ 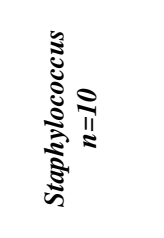 } & \multicolumn{2}{|c|}{ 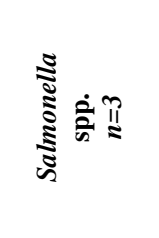 } & \multicolumn{2}{|c|}{ 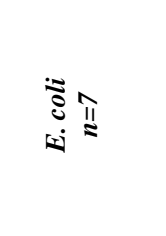 } & \multicolumn{2}{|c|}{ 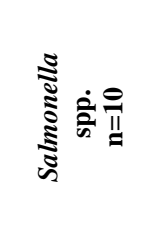 } & \multicolumn{2}{|c|}{ 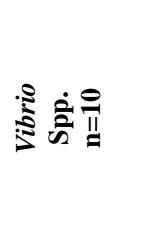 } & \multicolumn{2}{|c|}{ 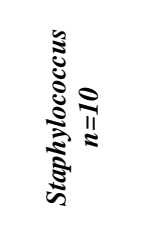 } & \multicolumn{2}{|c|}{ 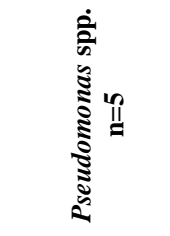 } \\
\hline & & $\begin{array}{c}\mathbf{R} \\
(\%)\end{array}$ & $\begin{array}{c}\mathbf{S} \\
(\%)\end{array}$ & $\begin{array}{c}\mathbf{R} \\
(\%)\end{array}$ & $\begin{array}{c}S \\
(\%)\end{array}$ & $\begin{array}{c}\mathbf{R} \\
(\%)\end{array}$ & $\begin{array}{c} \\
(\%)\end{array}$ & $\begin{array}{c}\mathbf{R} \\
(\%)\end{array}$ & $\begin{array}{c} \\
(\%)\end{array}$ & $\begin{array}{c}\mathbf{R} \\
(\%)\end{array}$ & $\begin{array}{c} \\
(\%)\end{array}$ & $\begin{array}{c}\mathbf{R} \\
(\%)\end{array}$ & $\begin{array}{c} \\
(\%)\end{array}$ & $\begin{array}{c}\mathbf{R} \\
(\%)\end{array}$ & $\begin{array}{c} \\
(\%) \\
\end{array}$ \\
\hline Polymixin B & $\begin{array}{c}300 \\
\text { units }\end{array}$ & 0 & 100 & 100 & 0 & 0 & 100 & 100 & 0 & 0 & 100 & & 100 & 0 & 0 \\
\hline Kanamycin & $30 \mu \mathrm{g}$ & 0 & 100 & 0 & 100 & 0 & 100 & 100 & 0 & 100 & 0 & 100 & 0 & 100 & 0 \\
\hline Methicillin & $30 \mu \mathrm{g}$ & 100 & 0 & 0 & 100 & 0 & 100 & 0 & 100 & 0 & 100 & 100 & 0 & 0 & 100 \\
\hline Streptomycin & $10 \mu \mathrm{g}$ & 0 & 100 & 0 & 100 & 0 & 100 & 0 & 100 & 0 & 100 & 0 & 100 & 0 & 100 \\
\hline Vancomycin & $30 \mu \mathrm{g}$ & 0 & 100 & 0 & 100 & 100 & 0 & 0 & 100 & 0 & 100 & 100 & 0 & 0 & 100 \\
\hline Gentamycin & $10 \mu \mathrm{g}$ & 0 & 100 & 50 & 50 & 0 & 100 & 0 & 100 & 0 & 100 & 0 & 100 & 0 & 100 \\
\hline Nalidixic acid & $30 \mu \mathrm{g}$ & 0 & 100 & 0 & 100 & 0 & 100 & 0 & 100 & 0 & 100 & 100 & 0 & 0 & 100 \\
\hline Azythromycin & $15 \mu \mathrm{g}$ & 0 & 100 & 0 & 100 & 0 & 100 & 0 & 100 & 100 & 0 & 100 & 0 & 100 & 0 \\
\hline Penicillin G & $10 \mu \mathrm{g}$ & 100 & 0 & 100 & 0 & 100 & 0 & 100 & 0 & 100 & 0 & 100 & 0 & 100 & 0 \\
\hline Erythromycin & $15 \mu \mathrm{g}$ & 100 & 0 & 100 & 0 & 0 & 100 & 100 & 0 & 0 & 100 & 100 & 0 & 100 & 0 \\
\hline Amoxicillin & $30 \mu \mathrm{g}$ & 100 & 0 & 100 & 0 & 100 & 0 & 100 & 0 & 100 & 0 & 100 & 0 & 100 & 0 \\
\hline Ceftriaxone & $30 \mu \mathrm{g}$ & 0 & 100 & 100 & 0 & 100 & 0 & 100 & 0 & 100 & 0 & 100 & 0 & 100 & 0 \\
\hline Ciprofloxacin & $5 \mu \mathrm{g}$ & 50 & 50 & 0 & 100 & 100 & 0 & 0 & 100 & 100 & 0 & 0 & 100 & 100 & 0 \\
\hline Ampicillin & $10 \mu \mathrm{g}$ & 0 & 100 & 0 & 100 & 100 & 0 & 100 & 0 & 100 & 0 & 100 & 0 & 100 & 0 \\
\hline Tetracycline & $30 \mu \mathrm{g}$ & 100 & 0 & 50 & 50 & 100 & 0 & 100 & 0 & 100 & 0 & 100 & 0 & 100 & 0 \\
\hline Chloramphenicol & $30 \mu \mathrm{g}$ & 0 & 100 & 0 & 100 & 100 & 0 & 100 & 0 & 100 & 0 & 100 & 0 & 0 & 100 \\
\hline Cefixime & $5 \mu \mathrm{g}$ & 0 & 100 & 0 & 100 & 100 & 0 & 100 & 0 & 100 & 0 & 100 & 0 & 100 & 0 \\
\hline
\end{tabular}

$\mathrm{R}=$ Resistan

$\mathrm{S}=$ Sensitive 
(table 2). Two isolates (Staphylococcus spp and Salmonella spp.) from fermented food frequently showed resistance against penicillin $\mathrm{G}$, erytromycin and amoxicillin while methicillin and tetracycline were found ineffective against Staphylococcus spp. (table 2). Conversely 5 isolates from the non-fermented food samples were found to be $100 \%$ sensitive against streptomycin $(10 \mu \mathrm{g})$ and gentamycin $(10 \mu \mathrm{g})$ while both strains showed resistance against more than one antibiotics such as azythromycin $(15 \mu \mathrm{g})$,penicillin $\mathrm{G}$ $(10 \mu \mathrm{g})$, erythromycin $(15 \mu \mathrm{g})$, amoxicillin $(30 \mu \mathrm{g})$, ceftriaxone $(30 \mu \mathrm{g})$, ciprofloxacin $(5 \mu \mathrm{g})$, ampicillin $(10$ $\mu \mathrm{g})$, tetracycline $(30 \mu \mathrm{g})$, chloramphenicol $(30 \mu \mathrm{g})$ and cefixime $(5 \mu \mathrm{g})$ (table 2$)$.

A number of research findings unveiled, the resistance gene might be evolved due to the mutation, genetic disorders, and mechanistic factors or by epidemiological factors which may creat huge obstacle in case disease medication $(3,30-32)$.

\section{CONCLUSION}

Overall, the present investigation discussed the compact microbiological profile of some popular food items both fermented and non-fermented consumed by Bangladeshi people as well as highlighted on the propagation of resistant bacteria in food items. Previously huge information have been gathered on the propagation of bacterial strain in general food and fermented food but unfortunately the study on fungal growth in fermented foods is very few. This study identified the presence of fungi in many popular fermented foods which may possibly get entry from the storage condition. Moreover, the presence of resistant strain in fermented foods is very much alarming which indicates the poor management set up and lack of proper legislation in food sector. In this perspective, the given information on the microbiological quality in accordance to the recommended microbiological criteria of different food items would impart a practical outcome in knowledge dissemination on food safety in Bangladesh.

\section{REFERENCES}

1. Toyofuku H. 2014. Foodborne diseases: prevalence of foodborne diseases in western pacific region. Encyclo. Food. Safety. 1: 312-322.

2. Noor R, Uddin MA, Hoque MA, Munshi SKM, Acharjee M, Rahman MM. 2013. Microbiological study of vendor and packed fruit juices locally available in Dhaka city, Bangladesh. Int. Food. Res. J. 20 (2): 1011-1015.

3. Acharjee M, Fatema K, Jahan F, Siddique SJ, Uddin MA, Noor R. 2013. Prevalence of Vibrio cholerae in different food samples in the city of Dhaka, Bangladesh. Int. Food. Res. J. 20 (2): 1017-1022.

4. Roy M, Harris J, Afreen S, Deak E, Gade L, Balajee SA, et al. 2013. Aflatoxin contamination in food commodities in Bangladesh. Food Additives and Contaminants: Part B: Surveillance. 6 (1): 16-23.

5. Rahman F. Noor R. 2012. Prevalence of pathogenic bacteria in common salad vegetables of Dhaka Metropolis. Bangladesh. J. of Botany. 41 (2): 159-162.

6. Centers for Disease Control and Prevention (CDC). 2014. Estimates of foodborne illness in the United States. CDC, Atlanta.
7. CAC (Codex Alimentarius Commission). 2007. Principles and guidelines for the conduct of microbiological risk management (MRM), CAC/GL-63. FAO, Rome.

8. FAO (Food and Agriculture Organization of the United Nations). 2004 Worldwide regulations for mycotoxins in food and feed in 2003. FAO, Rome, Italy.

9. FSANZ (Food Standards. Australia New Zealand). 2001. Guidelines for the microbiological examination of ready - to - eat foods. Available fromhttp://www.foodstandards.gov.au/publications/pages/guidelinesformicro bi1306.aspx. Accessed 18.10.2014.

10. Todd ECD. 2014. Foodborne diseases: Overview of biological hazards and foodborne diseases. Encyclo. Food. Safety. 1: 221-242.

11. Acharjee M, Jahan F, Rahman F, Noor R. 2013. Bacterial proliferation in municipal water supplied in mirpur locality of Dhaka city, Bangladesh. Clean - Soil. Air.Water. 41 (9999):1-8.

12. Clark JA, El-Shaarawi AH. 1993. Evaluation of commercial presenceabsence test kits for detection of total coliforms, Escherichia coli, and other indicator bacteria. Appl. Environ. Microbiol. 59: 380-388.

13. Clark RM, Geldreich EE, Fox KR, Rice EW, Johnson CH, Goodrich JA, et al. 1996. Tracking a Salmonella serovar typhimurium outbreak in Gideon, Missouri: role of contaminant propagation modelling. J. Water SRT-Aqua. 45: $171-183$.

14. Milićević DR, Skrinjar M, Baltic T. 2010. Real and perceived risks for mycotoxins contamination in foods and feeds: challenges for food safety control, Toxins. 2: 572-592.

15. Fraizer WC, Westhoff DC. 1995. Food Microbiology, $4^{\text {th }}$ ed. New Delhi.

16. Hesseltine CW. 1983. Microbiology of oriental fermented foods. Annual. Rev. Microbiol. 37: 575-601.

17. Franz MJ, Boucher JL, Evert AB. 2014. Evidence-based diabetes nutrition therapy recommendations are effective: the key is individualization. Diabetes Metab Syndr Obes.7: 65-72.

18. Stevens HC, Nabors L. 2009. Microbial food cultures: A regulatory update. Food Technolnol. 63: 36-41.

19. Holzapfel WH, Schillinger U, Toit MD, Dicks L. 1997. Systematics of probiotic lactic acid bacteria with reference to modern phenotypic and genomic methods. Micro-ecology and Therapy. 26: 1-10.

20. Holzapfel WH. 1989. Industrialization of Indigenous Fermented Foods. Marcel Dekker, New York.

21. Campbell-Platt G. 1987. Fermented Foods of the World: a Dictionary and guide. Butterworths, London, UK.

22. Steinkraus KH. 1997. Classification of fermented foods: worldwide review of household fermentation techniques. Food Con. 8: 311-317.

23. Tamang JP, Tamang B, Schillinger U, Guigas C, Holzapfel WH. 2009 Functional properties of lactic acid bacteria isolated from ethnic fermented vegetables of the Himalayas. Int. J. Food. Microbiol. 135: 28-33.

24. Steinkraus KH. 2002. Fermentations in World Food processing. Comprehensive reviews in food sciences and food safety. 1 (1): 23-32.

25. Steinkraus KH. 1997. Classification of fermented foods: worldwide review of household fermentation techniques. Food Control. 8: 311-317.

26. Farhad M, Kailasapathy K, Tamang JP. 2010. Fermented Foods and Beverages of the World. CRC Press, New York.

27. Nout MJR, Aidoo KE. 2002. The Mycota. Springer-Verlag, New York.

28. Olasupo NA, Odunfa SA, Obayori OS. 2010. Fermented Foods and Beverages of the World, CRC Press, Taylor \& Francis Group, New York.

29. Tenover FC. 2006. Mechanisms of Antimicrobial Resistance in Bacteria. American J. Med. 119: 3-10.

30. Bennett PM. 2008. Plasmid encoded antibiotic resistance: Acquisition and transfer of antibiotic resistance genes in bacteria. British J. Pharm. 153 (1): 347-357.

31. Canton R. 2009. Antibiotic resistance genes from the environment: A perspective through newly identified antibiotic resistance mechanisms in clinical setting. Euro. Soci. Clini. Microbiol Infec. Disea. 15 (1): 20-25.

32. Hung DT, Kaufman BB. 2010. The Fast track to multi-drug resistance. Int Mol. Cell Biology. 37 (3): 297-298.

33. Allerberger F, Mittermayer H. 2008. Antimicrobial stewardship. Clin. Microbiol Infect. Mar. 14 (3): 197-9.

34. APHA (American Public Health Association). 1998. Standard methods for the examination of water and wastewater. American Public Health Association, Washington, D.C.

35. Cappuccino JG, Sherman N. 1996. Microbiology - A laboratory manual. The Benjamin/Cummings Publishing Co., Inc., Menlo Park, California.

36. Acharjee M, Ahmed E, Munshi SK, Noor R. 2014. Validation of $\boldsymbol{\gamma}$ irradiation in controlling microorganisms in fish. Nutri. Food. Sci. 44 (3): 258-266.

37. Alfrad EB. 2007. Bensons Microbiological Applications. Mcgraw-Hill Book Company, New York

38. Bauer AW, Kirby WMM, Sherris JC, Tierch M. 1966. Antibiotic susceptibility testing by a standardized single disc method. American. J. Clini. Pathology. 45 (4): 493-496. 
39. Ferraro MJ, Craig WA. Dudley MN. 2001. Performance standards for antimicrobial susceptibility testing, $11^{\text {th }}$ ed. NCCLS, Pennsylvania, USA.

40. Anon. 2003. Codex Alimentarius Commission. Report of the Thirty-Fifth Session of the Codex Committee on Food Hygiene. Alinorm 03/13A Session of the Codex Committee on Food Hygiene.

41. Anon. 2004. Hygiene of foodstuffs. Regulation (EC) No. 852/2004

42. World Health Organization (WHO). 2002. Food safety issues: terrorist threats to food, guidance for establishing and strengthening prevention response systems. Food Safety Department, WHO Press, Geneva, Switzerland.

43. Foods Standards Australia New Zealand. 2011. Australia New Zealand Food Standards Code. Canberra (Australia): Foods Standards Australia New Zealand. Available from:

http://www.foodstandards.gov.au/foodstandards/foodstandardscode.cfm Accessed 10 February, 2011.
44. International Commission on Microbiological Specifications for food (ICMSF). 1986. Microorganisms in Food Sampling for Microbiological Analysis: Principle and Specific Application. Blackwell Scientific Publication

45. Obadina AO, Oyewole OB, Odubayo MO. 2007. Effect of storage on the safety and quality of "fufu" flour. J. Food Safety. 27: 148-156.

46. Obadina AO, Oyewole OB, Odusami AO. 2009. Microbiological safety and quality assessment of some fermented cassava products (lafun, fufu, gari) Sci. Res. Essay. 4 (5): 432-435.

47. Rompre' A, Servais P, Baudart J, De-Roubin M, Laurent P. 2002. Detection and enumeration of coliforms in drinking water: current methods and emerging approaches. J.Microbiol. Methods. 49: 31-54 